\title{
Isotopic differences in soil-plant-atmosphere continuum composition and control factors of different vegetation zones on the northern slope of the Qilian Mountains
}

\author{
Yuwei Liu ${ }^{1,2}$, Guofeng Zhu ${ }^{1,2}$, Zhuanxia Zhang ${ }^{1,2}$, Zhigang Sun ${ }^{1,2}$, Leilei Yong ${ }^{1,2}$, Liyuan Sang ${ }^{1,2}$, Lei Wang ${ }^{1,2}$, and \\ Kailiang Zhao ${ }^{1,2}$ \\ ${ }^{1}$ School of Geography and Environmental Science, Northwest Normal University, Lanzhou 730070, Gansu, China \\ ${ }^{2}$ Shiyang River Ecological Environment Observation Station, Northwest Normal University, Lanzhou 730070, Gansu, China
}

Correspondence: Guofeng Zhu (gfzhu@lzb.ac.cn)

Received: 14 May 2021 - Discussion started: 2 June 2021

Revised: 14 November 2021 - Accepted: 15 December 2021 - Published: 11 February 2022

\begin{abstract}
Understanding the differences and control factors of stable water isotopes in the soil-plant-atmosphere continuum (SPAC) of different vegetation zones is of great significance in revealing hydrological processes and regional water cycle mechanisms. From April 2018 to October 2019, we collected 1281 samples to investigated the stable water isotopes' changes in the SPAC of three different vegetation zones (alpine meadows, forests, and arid foothills) in the Shiyang River basin. The results show the following: (1) precipitation plays a major control role in the SPAC. From alpine meadows to arid foothills, the temperature effect of precipitation isotopes increases as altitude decreases. (2) From the alpine meadow to the arid foothills, soil water isotopes are gradually enriched. (3) Alpine meadow plants are mainly supplied by precipitation in the rainy season, and forest plants mainly utilize soil water in the dry season and precipitation in the rainy season. The soil water in the arid foothills is primarily recharged by groundwater, and the evaporation of plant isotopes is strong. (4) Temperature and altitude are potential factors that control the isotopic composition of the SPAC. This research will help in understanding of the SPAC system's water cycle at different altitudes and climates in high mountains.
\end{abstract}

\section{Introduction}

The relative abundance changes of hydrogen and oxygen isotopes in water can indicate the water cycle and the water use mechanism in plants, so isotope technology has become an increasingly important method to study the water cycle (Gao et al., 2009; Song et al., 2002; Coplen, 2013; Shou et al., 2013). The stable water isotopic composition is considered to be the "fingerprint" of water, which records a large amount of environmental information that comprehensively reflects the geochemical process of each system and links the composition characteristics of each link (Darling et al., 2003; Raco et al., 2013; Nlend et al., 2020). As an effective tool, stable-isotope technology is widely applied in studying the relationship between environmental factors and the water cycle (Araguás-Araguás et al., 1998; Christopher et al., 2009), water transportation and distribution mechanisms (Gao et al., 2011), and ways of tracing water use by plants (Detjen et al., 2015). The understanding of the relationship between the influence of plant characteristics, water use efficiency, and water sources (Ehleringer, 1991; Sun et al., 2005; Li et al., 2019) provides a new observation method for revealing the mechanism of the water cycle in the hydrological ecosystem (Nie et al., 2014; Yu et al., 2007; Wang et al., 2019). 
Although the isotopic ratio in soil water varies with depth, it remains stable when transferred from plant roots to stems, leaves, or young unbolted branches (Rodriguez-Iturbe, 2001; Meissne et al., 2014). Precipitation infiltration and runoff generation processes (Bam and Ireso, 2018; Hou et al., 2008) and groundwater recharge and regeneration capacity (Smith et al., 1992; Cortes and Farvolden, 1989) can be determined combining the isotopic composition changes of surface water, soil water, and groundwater. Regional meteorological and hydrological conditions and the contribution of various environmental factors can be evaluated (Hua et al., 2019) by comparing different waterline equations and analyzing changes in various water bodies. Furthermore, doing this has laid a foundation for studying the deep mechanism of the water cycle (Gao et al., 2009). As an important component of the global water cycle, plants control $50 \%-90 \%$ of transpiration (Jasechko et al., 2013; Coenders-Gerrits et al., 2014; Schlesinger and Jasechko, 2014). The plant's roots do not have isotope fractionation when absorbing water (White et al., 1985; Song et al., 2013), so the water isotopic composition of plant roots and stems reflects the isotope composition of water available for plants (Dawson et al., 1991).

The research of the water cycle based on the soil-plantatmosphere continuum (SPAC) plays a vital role in the study of water and the sources of plant water use in arid areas (Price et al., 2012; Shou et al., 2013). Hydrogen and oxygen isotopes have been used to study the water cycle at the interfaces of "soil-root", "soil-plant", and "soil-atmosphere", but only a few parameters play an important role in the complex interactions between the various surfaces (Durand et al., 2007; Li et al., 2006; West et al., 2010). Previous studies have shown that local factors, especially temperature, mainly control stable-isotope precipitation changes in mid-latitudes (Dai et al., 2020). Through research on the composition of hydrogen and oxygen isotopes in different water bodies, we can further understand the mechanism of water use by vegetation (Yang et al., 2015) and provide a scientific basis for vegetation restoration in arid and semi-arid areas. In the existing research, how to extend the results of the small-scale SPAC water cycle research to the large-scale area has become a difficult hot spot. In inland arid areas, due to the lack of water resources, the exchange of energy and water with the outside world is small, and the water cycle is mainly the vertical circulation of groundwater-soil-atmospheric water. Therefore, studying the changes in SPAC isotopic composition in arid regions is significant for ecological restoration.

The Shiyang River basin is under the greatest ecological pressure and has the most severe water shortage in China. The purpose of this study is to (1) analyze the SPAC water cycle process in different vegetation zones and (2) identify the potential factors that control the SPAC water cycle. This research is helpful to clarify the water resource utilization mechanism and the local water cycle mechanism of different vegetation areas in high mountainous areas and provide a theoretical basis for the reasonable use of water resources in arid areas.

\section{Materials and methods}

\subsection{Study area}

The Shiyang River basin is located at the northern foot of the Qilian Mountains, east of the Hexi region, Gansu Province (Zhu et al., 2018) (Fig. 1). The Shiyang River originates from the snowcapped mountains on the north side of the Lenglongling in the eastern section of the Qilian Mountains. The river's total length is about $250 \mathrm{~km}$, with a basin area of $4.16 \times 104 \mathrm{~km}^{2}$, and the annual average runoff is about $1.58 \times 108 \mathrm{~km}^{3}$. Rivers are supplied by precipitation from mountain and alpine ice and snow meltwater. The runoff area is about $1.10 \times 104 \mathrm{~km}^{2}$, and the drought index is 1 to 4 (Zhou et al., 2020). The soil is classified as grey-brown desert soil, eolian sandy soil, saline soil, and meadow soil. The Shiyang River basin has a continental temperate arid climate with strong sunlight. The annual average sunshine hours are 2604.8-3081.8 $\mathrm{h}$; the annual average temperature is -8.2 to $10.5^{\circ} \mathrm{C}$; the temperature difference between day and night is $25.2^{\circ} \mathrm{C}$; the annual average precipitation is $222 \mathrm{~mm}$; and the annual average evaporation is $700-2000 \mathrm{~mm}$. The vegetation coverage in the upper and middle alpine regions is better than that of the lower reaches, with trees, shrubs, and grasscovered vegetation categories (Wan et al., 2019). The downstream vegetation coverage is poor under the strong influence of long-term human production, mainly desert vegetation.

\subsection{Sample collection}

From April 2018 to October 2019, samples were collected at Lenglong (alpine meadow), Hulin (forest), and Xiying (arid foothills) in the Shiyang River basin (Table 1). We collected 1281 samples in the Shiyang River basin, including 472 precipitation samples, 570 soil samples, 119 plant samples, and 120 groundwater samples.

The precipitation samples were collected with a rain bucket. The rain measuring cylinder consists of a funnel and a storage part. After each precipitation event, we immediately transferred the liquid precipitation to a $100 \mathrm{~mL}$ highdensity sample bottle. The sample bottle was sealed with a sealing film and stored at low temperature. Simultaneously, the polyethylene bottle sample was labeled with the date and type of precipitation (rain, snow, hail, and rain).

The soil samples were collected at intervals of $10 \mathrm{~cm}$ at a depth of $100 \mathrm{~cm}$ with a soil drill. Part of the soil sample was put into a $50 \mathrm{~mL}$ glass bottle. The bottle's mouth was sealed with parafilm and transported to the observation station for cryopreservation within $10 \mathrm{~h}$ of sampling. The remaining soil sample was placed in a $50 \mathrm{~mL}$ aluminum box, and we used the drying method to measure the soil water content (swc). 

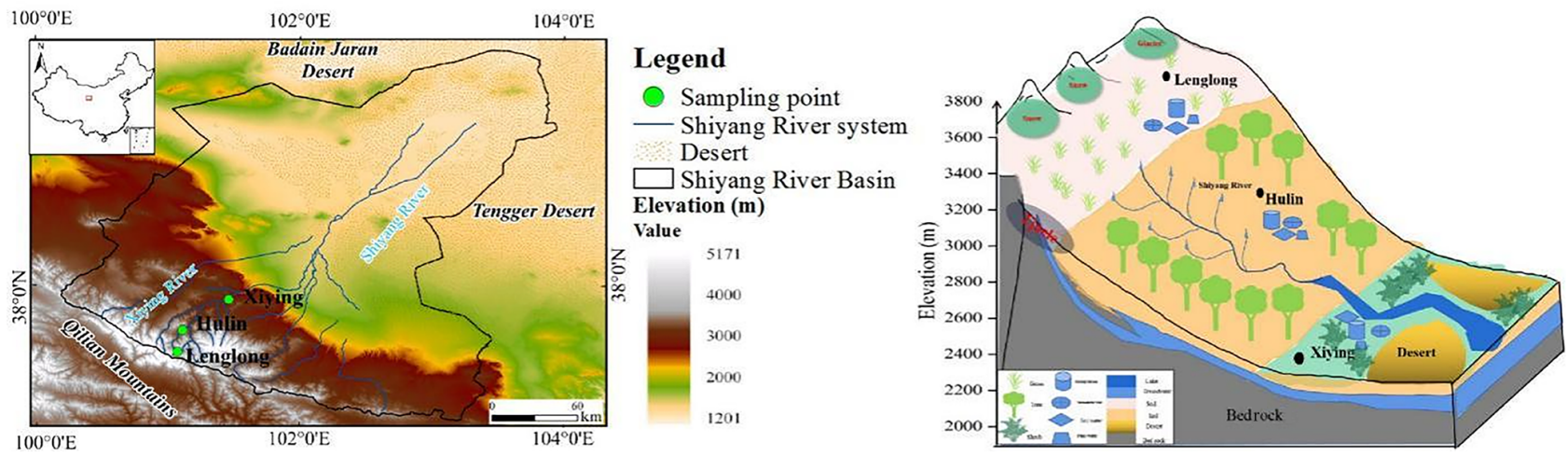

Figure 1. Study area and observation system.

Table 1. Basic information table of sampling points.

\begin{tabular}{|c|c|c|c|c|c|c|}
\hline \multicolumn{2}{|c|}{ Sampling station } & \multicolumn{3}{|c|}{ Geographical parameters } & \multicolumn{2}{|c|}{ Meteorological parameters } \\
\hline & & Latitude $(\mathrm{N})$ & Longitude (E) & Altitude (m) & Average annual temperature $\left({ }^{\circ} \mathrm{C}\right)$ & Average annual precipitation $(\mathrm{mm})$ \\
\hline M1 & Lenglong & $37^{\circ} 33^{\prime}$ & $101^{\circ} 50^{\prime}$ & 3647 & -0.20 & 595.10 \\
\hline M2 & Hulin & $37^{\circ} 41^{\prime}$ & $101^{\circ} 53^{\prime}$ & 2721 & 3.24 & 469.44 \\
\hline M3 & Xiying & $38^{\circ} 29^{\prime}$ & $102^{\circ} 18^{\prime}$ & 2097 & 7.99 & 194.67 \\
\hline
\end{tabular}

The vegetation samples were collected with a sampling shear. First, we peeled off the bark and put the stem into a $50 \mathrm{~mL}$ glass bottle. After that, we sealed the bottle mouth and kept it frozen before the experimental analysis.

The groundwater samples were collected with polyethylene bottles, and the samples were brought back to the refrigerator at the test station for cryogenic preservation within $10 \mathrm{~h}$.

\subsection{Sample treatment}

All water samples were tested using a liquid-water isotope analyzer (LWIA; DLT-100, Los Gatos Research, USA) at the Northwest Normal University laboratory. Each sample and isotopic standard were analyzed by six consecutive injections. To eliminate the memory effect of the analyzer, we discarded the values of the first two injections and used the average of the last four injections as the final result value. Isotopic measurements are given with the symbol " $\delta$ " and are expressed as a difference of thousandths relative to $\mathrm{Vi}$ enna Standard Mean Ocean Water:

$\left.\delta(\% o)=\left[\left(\delta / \delta_{\mathrm{V} \text {-smow }}\right)-1\right)\right] \cdot 1000$,

where $\delta$ is the ratio of ${ }^{18} \mathrm{O} /{ }^{16} \mathrm{O}$ or $\mathrm{D} /{ }^{1} \mathrm{H}$ in the collected sample and $\delta_{\mathrm{v} \text {-smow }}$ is the ratio of ${ }^{18} \mathrm{O} /{ }^{16} \mathrm{O}$ or $\mathrm{D} /{ }^{1} \mathrm{H}$ in the Vienna standard sample.

Due to the existence of methanol and ethanol in plant water samples, it is necessary to calibrate the raw data of plant samples. To determine the methanol (NB) and ethanol (BB) pollution degree, we used different concentrations of pure methanol and ethanol mixed deionized water, combined with Los Gatos' LWIA spectral pollutant identification instrument V1.0 spectral analysis software, and then we established calibration methods for $\delta \mathrm{D}$ and $\delta^{18} \mathrm{O}$ spectral contaminants (Meng et al., 2012; Liu et al., 2015). For the broadband metric value NB metric of the methanol calibration result, its logarithm has a significant quadratic-curve relationship with $\Delta \delta \mathrm{D}$ and $\Delta \delta^{18} \mathrm{O}$, and the formulas are, respectively,

$$
\begin{aligned}
\Delta \delta \mathrm{D}= & 0.018(\ln \mathrm{NB})^{3}+0.092(\ln \mathrm{NB})^{2}+0.388 \ln \mathrm{NB} \\
+ & 0.785\left(R^{2}=0.991 ; p<0.0001\right), \\
\Delta \delta^{18} \mathrm{O}= & 0.017(\ln \mathrm{NB})^{3}-0.017(\ln \mathrm{NB})^{2}+0.545 \ln \mathrm{NB} \\
& +1.358\left(R^{2}=0.998 ; p<0.0001\right) .
\end{aligned}
$$

For ethanol calibration results, the broadband metric value $\mathrm{BB}$ metric has a quadratic curve and a linear relationship with $\Delta \delta \mathrm{D}$ and $\Delta \delta^{18} \mathrm{O}$, and the formulas are, respectively,

$$
\begin{gathered}
\Delta \delta \mathrm{D}=-85.67 \mathrm{BB}+93.664 \\
\left(R^{2}=0.747 ; p=0.026\right)(\mathrm{BB}<1.2), \\
\Delta \delta^{18} \mathrm{O}=-21.421 \mathrm{BB}^{2}+39.9356 \\
\left(R^{2}=0.769 ; p<0.012\right) .
\end{gathered}
$$

\subsection{Data analysis}

Since the isotopic data are generally normally distributed according to the Kolmogorov-Smirnov (KS) test, we used Pearson correlation to describe the various correlations between different water types (precipitation, soil water, plant water, and groundwater) and the control factors in different 


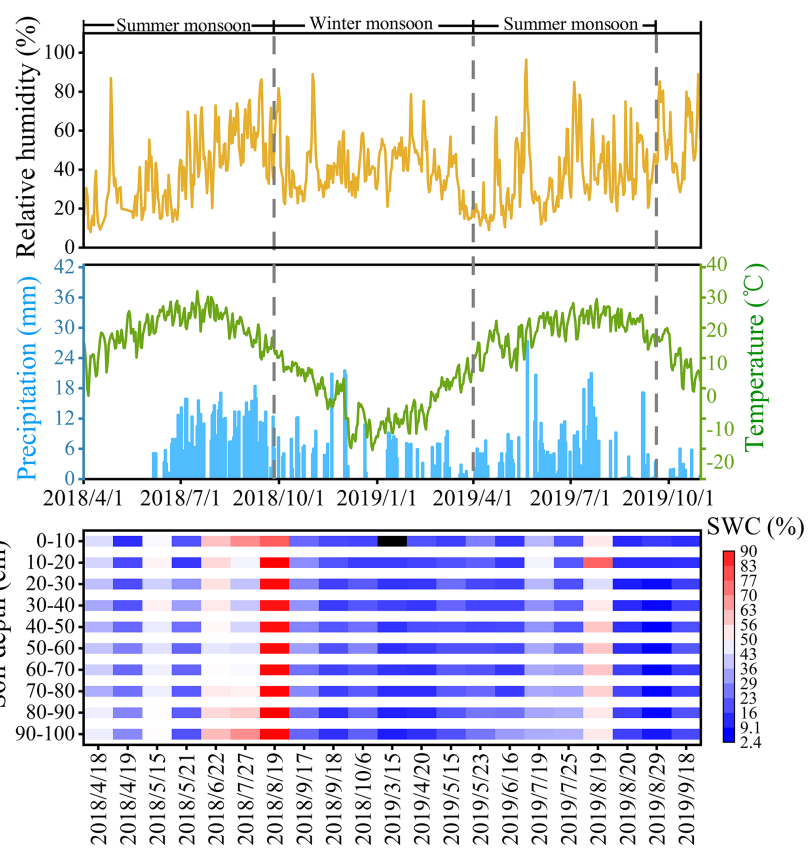

Figure 2. Diurnal variation in relative humidity, precipitation, temperature, and swc (\%) from April 2018 to October 2019. The date is given in the format year/month/day.

vegetation zones. The significance level for all statistical tests was set to the $95 \%$ confidence interval. All statistical analyses were completed using SPSS software.

\section{Results}

\subsection{Changes in meteorological parameters over time}

Figure 2 shows the changes in daily precipitation, relative humidity, temperature, and swc from April 2018 to October 2019. Meteorological data are obtained from the meteorological station in the Shiyang River basin. During the summer monsoon (April to September), the accumulated precipitation accounts for $90.4 \%$ of the total precipitation, and the daily average precipitation is $3.98 \mathrm{~mm}$. During the winter monsoon (October to March), the accumulated precipitation accounts for $9.60 \%$ of the total precipitation, with average daily precipitation of $0.13 \mathrm{~mm}$. During the summer monsoon, the relative humidity of the Shiyang River basin is $43.78 \%$, while during the winter monsoon it is $35.78 \%$. During the observation period, the temperature is -16.2 and $32{ }^{\circ} \mathrm{C}$, and the average temperatures of the summer monsoon and winter monsoon are 20.20 and $-0.69^{\circ} \mathrm{C}$, respectively. The average swc value of the $0-100 \mathrm{~cm}$ soil layer vary from $2.58 \%$ to $89.96 \%$, and the low swc value usually appears in summer, which is related to strong soil evaporation.

\subsection{The relationship between stable water isotopes in different vegetation zones}

According to the definition of the global meteoric water line (GMWL) (Craig, 1961), the linear relationship of $\delta^{18} \mathrm{O}$ and $\delta \mathrm{D}$ in local precipitation, soil water, plant water, and groundwater is defined as LMWL, SWL, PWL, and GWL, respectively.

As shown in Fig. 3, there are some differences in the local meteoric waterline equations of different vegetation zones. The slopes of the LMWL of alpine meadows (7.88), forests (7.82), and arid foothills (7.72) are all smaller than that of the GMWL (8.00); this is because the study area is located in northwestern China's arid area, where the climate is dry, and the isotopes have undergone strong fractionation. The slope of the SWL in the alpine meadow is the largest (6.07), and the slope of the SWL in the forest (5.10) is greater than the slope of the SWL in the arid foothills (3.94); the intercept has the same characteristics, indicating that the arid foothills' soil evaporation is the largest. According to the Investigation Report on Natural Resources in the Shiyang River basin in 2020 , the vegetation coverage rate of the alpine meadow is $25.95 \%$ and that of the arid foothills is $8.48 \%$. The vegetation coverage rate of the alpine meadow is higher than that of the arid foothills, and it has better water retention ability and less evaporation of soil water (Wan et al., 2019; Wei et al., 2019). The slope of the PWL in the arid foothills is the largest (2.45), and the slope of the PWL in the alpine meadow (1.90) is greater than that of the forest (1.69).

According to the weighted average value of stable oxygen isotopes of various water bodies (Table 2), alpine meadows' soil water $\delta^{18} \mathrm{O}$ is $-9.16 \%$, which is the most depleted and the closest to the precipitation $\delta^{18} \mathrm{O}(-9.44 \%)$. The average $\delta^{18} \mathrm{O}$ of groundwater is $-8.84 \%$, which is between the $\delta^{18} \mathrm{O}$ of plant $\left(-1.68 \%\right.$ ) and $\delta^{18} \mathrm{O}$ of precipitation $(-9.44 \%$ ) indicating that precipitation is the primary source of alpine meadow replenishment. The average $\delta^{18} \mathrm{O}$ of groundwater $\left(-8.56 \%\right.$ ) is between soil water $\delta^{18} \mathrm{O}(-7.01 \%$ ) and precipitation $\delta^{18} \mathrm{O}(-8.63 \%)$, but it is closer to precipitation $\delta^{18} \mathrm{O}$, indicating that forest groundwater is replenished by soil water and precipitation. The mean $\delta^{18} \mathrm{O}$ values of soil water $(-8.23 \%$ ) in the arid foothills are between precipitation $\delta^{18} \mathrm{O}(-7.50 \%)$ and groundwater $\delta^{18} \mathrm{O}(-8.88 \% 0)$ but closer to groundwater $\delta^{18} \mathrm{O}$, indicating that the soil water in the arid foothills is mainly supplied by groundwater.

\subsection{Relationship between soil water and plant water isotopes in different vegetation zones}

By analyzing the isotopic composition of soil and plant xylem, it is possible to preliminarily determine whether there is an overlap between soil moisture and plant moisture at different depths (Javaux et al., 2016; Dawson et al., 1993; Rothfuss et al., 2017; Tetzlaff et al., 2017; McCole et al., 2007; Zhou et al., 2015; Schwendenmann et al., 2015). Soil water 


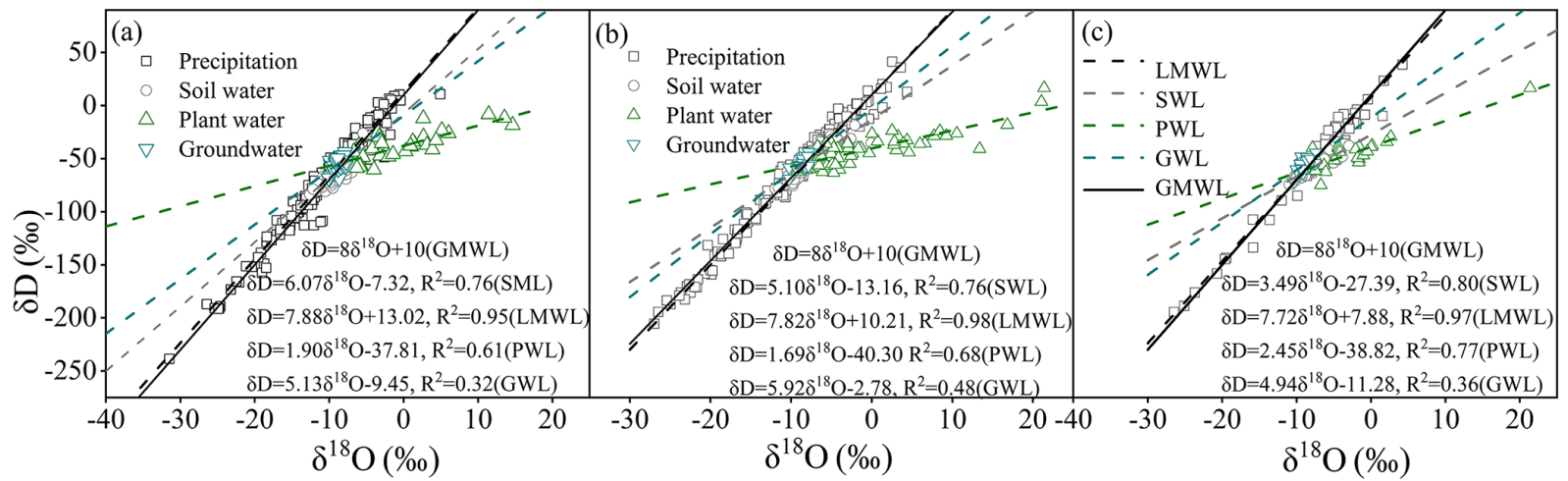

Figure 3. Relationship of stable isotopes in different water bodies in alpine meadow (a), forest (b), and arid foothills (c).

Table 2. Comparison of stable isotopes of water in different vegetation zones.

\begin{tabular}{|c|c|c|c|c|c|c|c|c|c|}
\hline \multirow{2}{*}{$\begin{array}{l}\text { Vegetation zone } \\
\text { types }\end{array}$} & \multirow[t]{2}{*}{ Water types } & \multicolumn{4}{|c|}{$\delta^{18} \mathrm{O}(\% \circ)$} & \multicolumn{4}{|c|}{$\delta \mathrm{D}(\%)$} \\
\hline & & Min & Max & Average & Coefficient of variation & Min & Max & Average & Coefficient of variation \\
\hline \multirow[t]{4}{*}{ Alpine meadow } & Precipitation & -31.49 & 14.79 & -9.44 & -0.70 & -238.62 & 63.43 & -59.43 & -0.84 \\
\hline & Soil water & -12.62 & -5.46 & -9.16 & -0.16 & -83.86 & -26.13 & -62.92 & -0.16 \\
\hline & Plant water & -6.68 & 5.12 & -1.68 & -2.18 & -60.22 & -12.14 & -41.14 & -0.28 \\
\hline & Groundwater & -10.07 & -7.71 & -8.84 & -0.07 & -68.55 & 43.72 & -54.85 & -0.10 \\
\hline \multirow[t]{4}{*}{ Forest } & Precipitation & -26.96 & 4.38 & -8.63 & -0.74 & -205.40 & 41.35 & -60.24 & -0.87 \\
\hline & Soil water & -11.96 & -0.07 & -7.01 & -0.25 & -78.43 & -18.48 & -48.68 & -0.21 \\
\hline & Plant water & -9.24 & 5.98 & -5.44 & -1.31 & -63.29 & -23.77 & -45.12 & -0.24 \\
\hline & Groundwater & -10.25 & -7.43 & -8.56 & -0.09 & -68.80 & -43.75 & -53.46 & -0.12 \\
\hline \multirow[t]{4}{*}{ Arid foothills } & Precipitation & -26.47 & 4.24 & -7.50 & -0.87 & -194.34 & 38.62 & -48.62 & -1.04 \\
\hline & Soil water & -10.98 & -2.96 & -8.23 & -0.15 & -74.22 & -8.79 & -59.17 & -0.12 \\
\hline & Plant water & -9.41 & 2.67 & -3.61 & -0.88 & -74.90 & -29.39 & -48.79 & -0.23 \\
\hline & Groundwater & -10.34 & -7.43 & -8.88 & -0.07 & -71.67 & -44.26 & -55.12 & -0.09 \\
\hline
\end{tabular}

may evaporate before being absorbed by plants, which leads to an increase in $\delta \mathrm{D}$ and $\delta^{18} \mathrm{O}$ values of soil water (Chen et al., 2014). Therefore, it can be well explained that the surface soil water isotope in Fig. 4 is more enriched than the deep soil water isotope.

According to the study area's precipitation, the current experiment is divided into the dry season (October-April of the following year) and the rainy season (May-September) for analysis (Fig. 4). In the dry season, alpine meadow plants have the highest value of $\delta^{18} \mathrm{O}(-2.84 \%$ ), and there is no overlap between soil and plant water. In the rainy season, the plant water $\delta^{18} \mathrm{O}\left(-6.04 \%\right.$ ) and precipitation $\delta^{18} \mathrm{O}$ $(-6.40 \%$ ) are close and the groundwater and soil water's surface and deep layers intersect, indicating that plant water is mainly supplied by precipitation in the rainy season, while the groundwater is supplied by soil water. In the dry season, due to the low temperature (average temperature $0.30^{\circ} \mathrm{C}$ ), there is a lot of ice and snow in alpine meadows, and plants do not directly use soil water. As temperature increases (average temperature $8.72^{\circ} \mathrm{C}$ ), precipitation and surface runoff increase and water infiltrates groundwater from soil. Forest plant water intersects with deep soil during the dry season and intersects with the soil surface during the rainy season, indicating that forest plants mainly use deep soil water during the dry season and shallow soil water during the rainy season. In the rainy season, the surface layer of soil water intersects with plant water and the groundwater and soil water's surface and deep layers intersect, showing that the plant water preferentially uses the surface layer water of the soil in the arid foothills. In the dry season, plant water oxygen is the most enriched, and the isotopic values of groundwater and soil water are close, indicating that the soil water is mainly recharged by the groundwater. According to the Natural Resources Survey Report of the Shiyang River basin, the buried groundwater level in the arid foothills is $2.5-15 \mathrm{~m}$, and the groundwater table is relatively shallow, making the soil water in the arid foothills mainly recharged by groundwater in the dry season. 

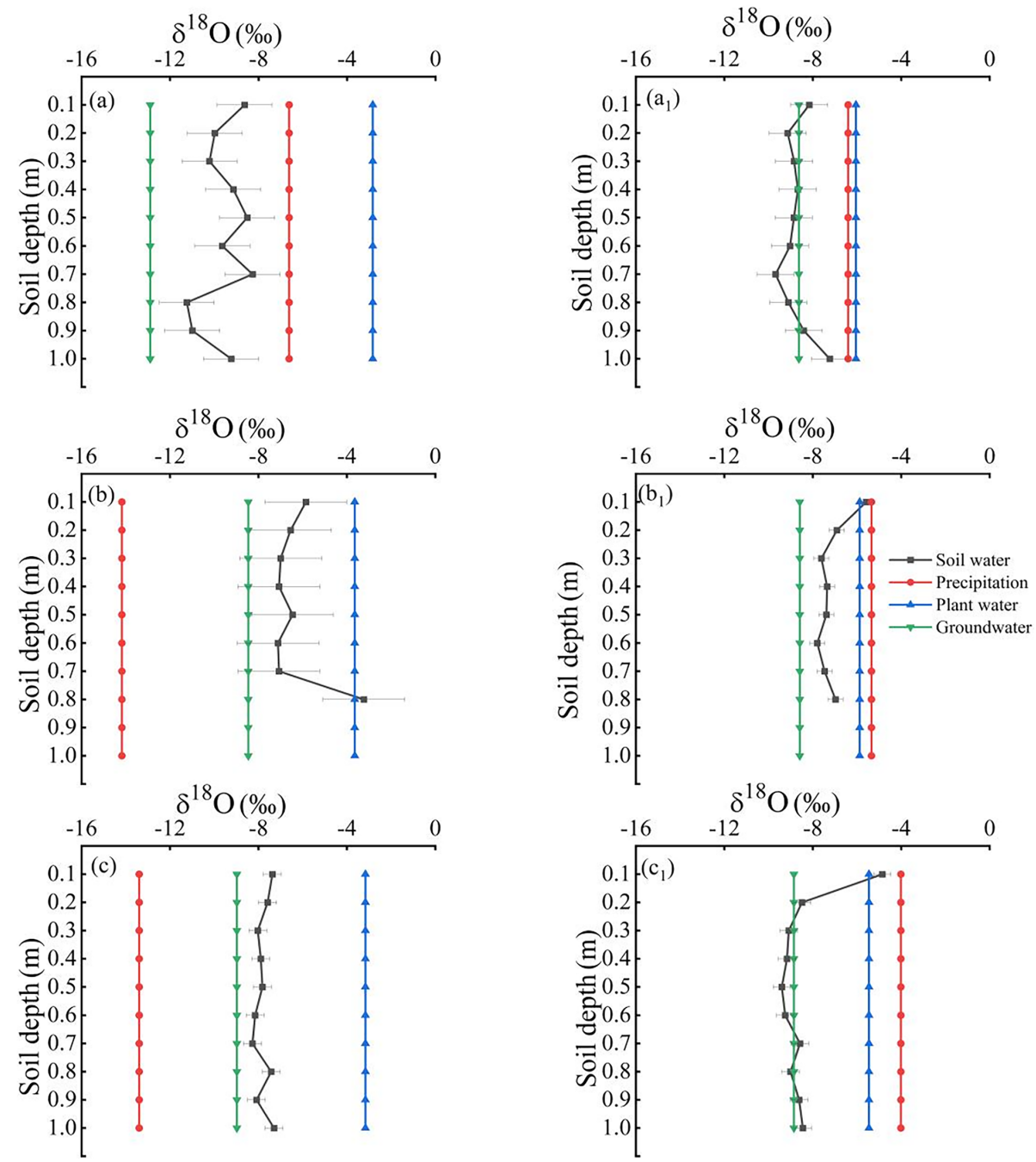

Figure 4. Panels $(\mathbf{a}-\mathbf{c})$ represent the variation in $\delta^{18} \mathrm{O}$ of soil, plant, precipitation, and groundwater with soil depth in the alpine meadow, forests, and arid foothills in the dry season, and panels (a1-c1) represent the variation in $\delta^{18} \mathrm{O}$ of soil, plant, precipitation, and groundwater in the alpine meadow, forests, and arid foothills in the rainy season.

\section{Discussion}

\subsection{Variation in soil water isotopes and swc between different vegetation zones}

In Fig. 5, along the three vegetation zones of alpine meadow, forest, and arid foothills, soil water isotopes are gradually enriched. The coefficient of variation of the arid foothills is the largest $(-0.15)$, while that of the forest is the smallest $(-0.25)$, indicating that from forest to arid foothills, the closer to arid regions, the greater the coefficient of variation and the greater the instability of soil water isotopes. The soil water isotopes of different vegetation zones showed the same characteristics as the soil depth changed; that is, they were all depleted in May and August and enriched in October.

The swc of alpine meadows (average $\theta$ of $42.21 \%$ ) is higher than that of forests (average $\theta$ of $26.98 \%$ ) and arid foothills (average $\theta$ of $17.05 \%$ ), and the swc of alpine meadows increases with the increase in soil depth (from $43.78 \%$ to $49.27 \%$ ), while that of forests decreases with the soil depth (from $26.10 \%$ to $25.41 \%$ ). Compared with forests, plants in alpine meadows have shallower root systems and smaller canopies, so transpiration and water consumption are lower and swc is higher (Csilla et al., 2014; Li et al., 2009; Western et al., 1998). On the one hand, with improvement in vegetation restoration, the ability of alpine meadows to retain soil water has been enhanced and soil water evaporation has reduced. On the other hand, Lenglong, a representative of alpine meadows, has average annual precipitation of $595.10 \mathrm{~mm}$ and a low temperature (average annual temperature of $-0.20^{\circ} \mathrm{C}$ ), making the soil water evaporation intensity weak. The swc of the alpine meadows $(86.95 \%)$ and forests $(53.45 \%)$ is the largest in August, while the arid foothills' swc (11.13\%) is the smallest in August; this is be- 

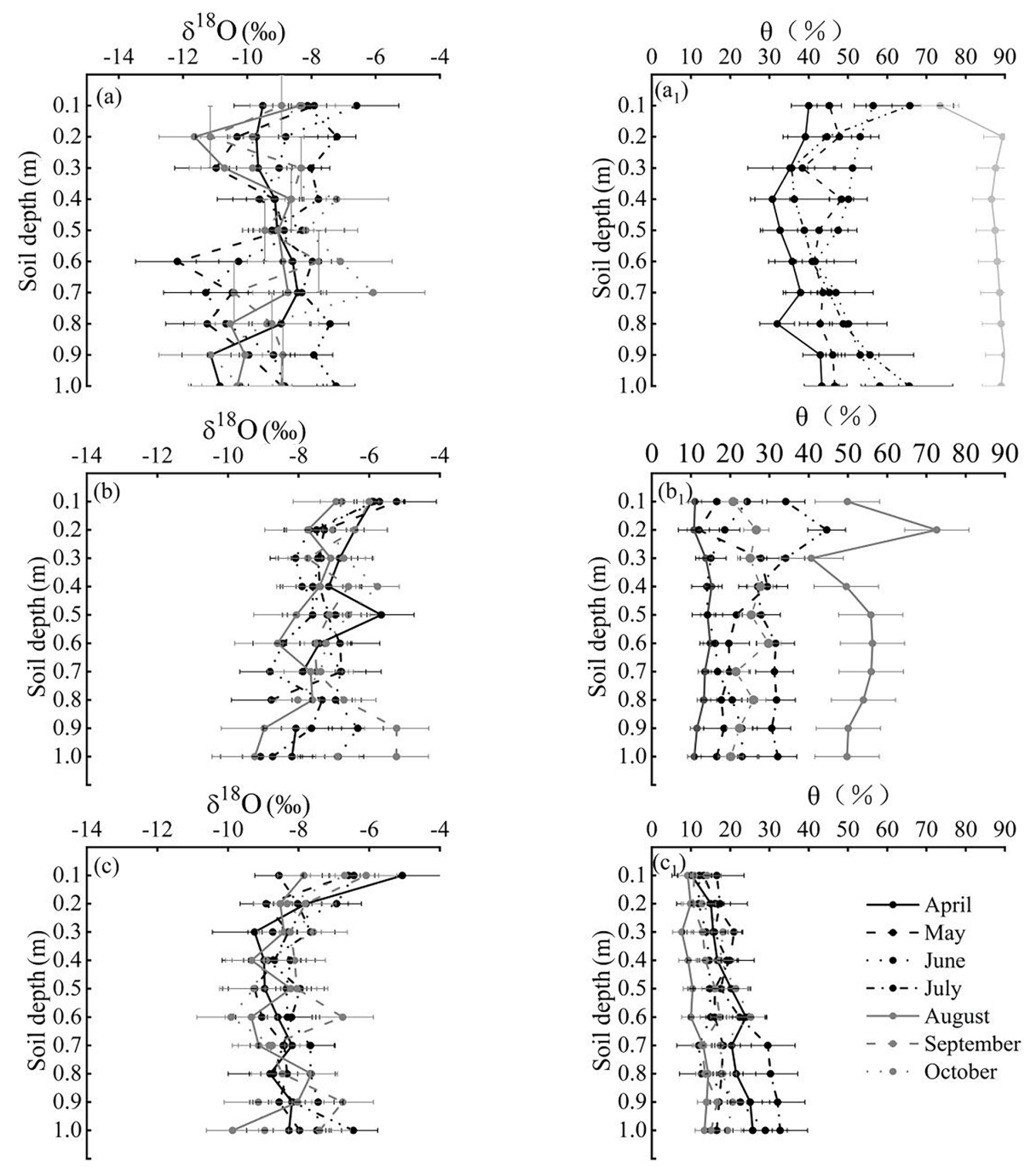

Figure 5. The variation in $\delta^{18} \mathrm{O}$ and soil water content $(\theta, \%)$ with soil depth. Panels (a-c) represent alpine meadow, forests and arid foothills, respectively.

cause the northern slope of the Qilian Mountains is a windward slope. In August, a lot of precipitation falls on the highaltitude alpine meadows and forests, while the arid foothills have little precipitation and low swc.

\subsection{Control factors of the SPAC in different vegetation zones}

\subsubsection{The influence of temperature on SPAC}

As shown in Fig. 6, with the changes in the water cycle of precipitation-soil water-plant water, the $\delta^{18} \mathrm{O}$ of forests is gradually enriched, while the soil water $\delta^{18} \mathrm{O}$ values of arid foothills and alpine meadows are the most depleted in summer. In other seasons, $\delta^{18} \mathrm{O}$ is gradually enriched along with precipitation-soil water-plant water. In summer, there is much precipitation and high swc in alpine meadows, but due to the low temperature (average temperature in summer is $9.80^{\circ} \mathrm{C}$ ), the soil water $\delta^{18} \mathrm{O}$ of alpine meadows is relatively depleted. In the arid foothills, in summer, especially in August, although the temperature is relatively high (the average temperature is $23.92{ }^{\circ} \mathrm{C}$ ), the swc is low, evaporation is weak, and $\delta^{18} \mathrm{O}$ is relatively depleted. This phenomenon shows that precipitation plays a major control role in the water cycle of precipitation-soil-plants. When the temperature is below $0{ }^{\circ} \mathrm{C}$, the air will expand adiabatically, and the water vapor will change adiabatic cooling (Rozanski, 1992). When the temperature is between 0 and $8^{\circ} \mathrm{C}$, the influence of local water vapor circulation is greater. When the temperature is below $8^{\circ} \mathrm{C}$, the below-cloud evaporation is very strong (Zhu et al., 2021a). Therefore, we divided the temperature into three gradients (below $0{ }^{\circ} \mathrm{C}$, between 0 and $8^{\circ} \mathrm{C}$, and above $8^{\circ} \mathrm{C}$ ) for analysis. From the alpine meadow to forest to arid foothills, the correlations between temperature and soil $\delta^{18} \mathrm{O}$ are $0.41,0.30$, and 0.19 , respectively, and the cor- 

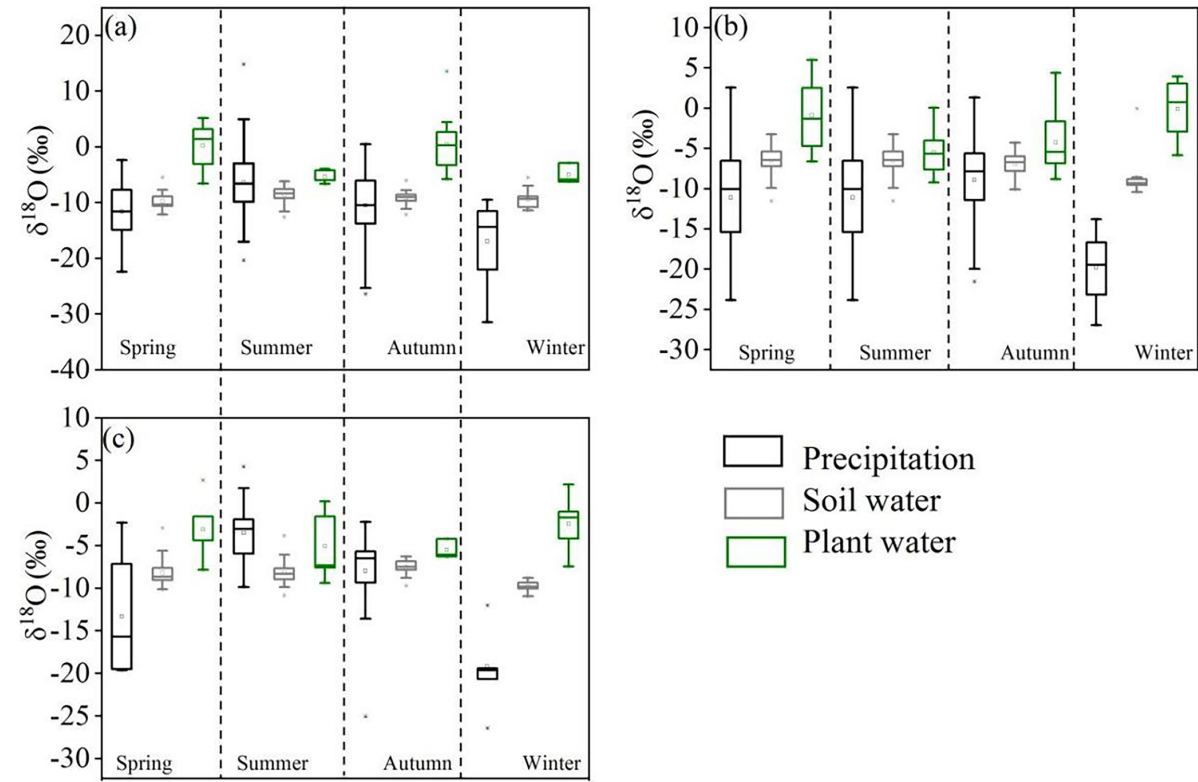

Precipitation

Soil water

Plant water

Figure 6. Seasonal variations in different water isotopes in alpine meadow (a), forests (b), and arid foothills (c).

Table 3. Correlation between precipitation isotopes and different temperatures in different vegetation zones.

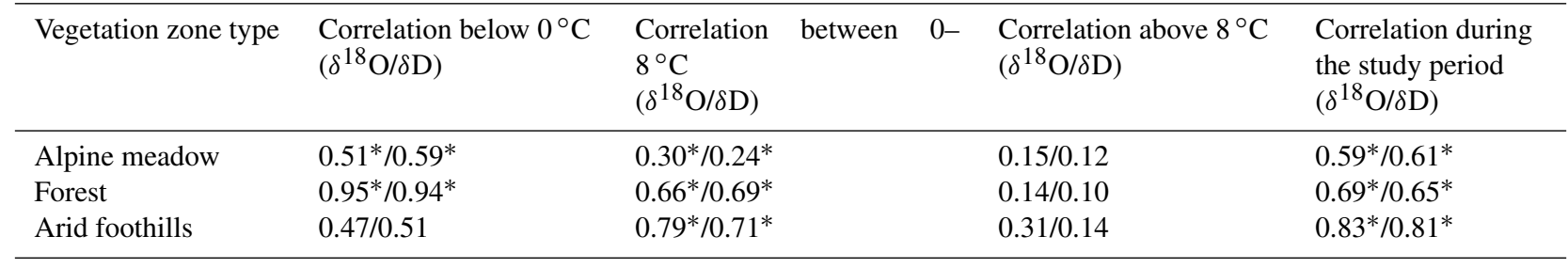

* A significant correlation (two-tailed) at a confidence level of 0.05 .

relations with plant $\delta^{18} \mathrm{O}$ are $0.24,0.27$, and 0.25 , respectively, and the temperature effect is not significant compared with precipitation. As shown in Table 3, from the alpine meadow to the arid foothills, the temperature effect of the precipitation isotope increased, and there is a significant positive correlation with temperature and all correlations have passed the significance test. With the increase in temperature, the linear relationship between temperature and precipitation isotopes in each vegetation zone became weaker. When the temperature is lower than $0{ }^{\circ} \mathrm{C}$, the correlation between precipitation $\delta^{18} \mathrm{O}$ and the temperature in the arid foothills fails to pass the significance test. The relationships between $\delta^{18} \mathrm{O}$ and temperature in alpine meadows, forests, and arid foothills are $\delta^{18} \mathrm{O}=0.62 \mathrm{~T}-10.84, \delta^{18} \mathrm{O}=1.58 T-12.14$, and $\delta^{18} \mathrm{O}=1.29 \mathrm{~T}-11.78$, respectively. When the temperature is between 0 and $8^{\circ} \mathrm{C}$, the temperature effect of precipitation weakens with the temperature increases, which may be related to the weakening of the local water cycle and the enrichment of precipitation isotopes. The relationships between $\delta^{18} \mathrm{O}$ and temperature in alpine meadows, forests, and arid foothills are $\delta^{18} \mathrm{O}=0.51 T-11.41, \delta^{18} \mathrm{O}=2.46 T-22.84$, and $\delta^{18} \mathrm{O}=2.27 T-22.78$, respectively. When the temperature is above $8{ }^{\circ} \mathrm{C}$, there is no correlation between the precipitation $\delta^{18} \mathrm{O}$ and the temperature, but the precipitation $\delta^{18} \mathrm{O}$ is the most enriched, which may be related to the $\delta^{18} \mathrm{O}$ enrichment caused by the below-cloud evaporation. The relationships between $\delta^{18} \mathrm{O}$ and temperature in alpine meadows, forests, and arid foothills are $\delta^{18} \mathrm{O}=0.48 T-10.82$, $\delta^{18} \mathrm{O}=0.13 T-7.76$, and $\delta^{18} \mathrm{O}=0.27 T-10.13$, respectively.

\subsubsection{The influence of altitude on the SPAC}

In Fig. 7, the altitude effect of precipitation $\delta^{18} \mathrm{O}$ is the strongest and the relationship between plant water $\delta^{18} \mathrm{O}$ and altitude is the weakest, showing that in the SPAC, precipitation isotopes are most affected by altitude and plant water isotopes are least affected by altitude. From the arid foothills to alpine meadows, the elevation increases from 2097 to $3647 \mathrm{~m}$, and the change rate of $\delta^{18} \mathrm{O}$ and $\delta \mathrm{D}$ is -0.11 and $-0.41 \%(100 \mathrm{~m})^{-1}$. As the water vapor quality increases along the hillside, the temperature continues to decrease and the isotopic values of precipitation continue to deplete. In 

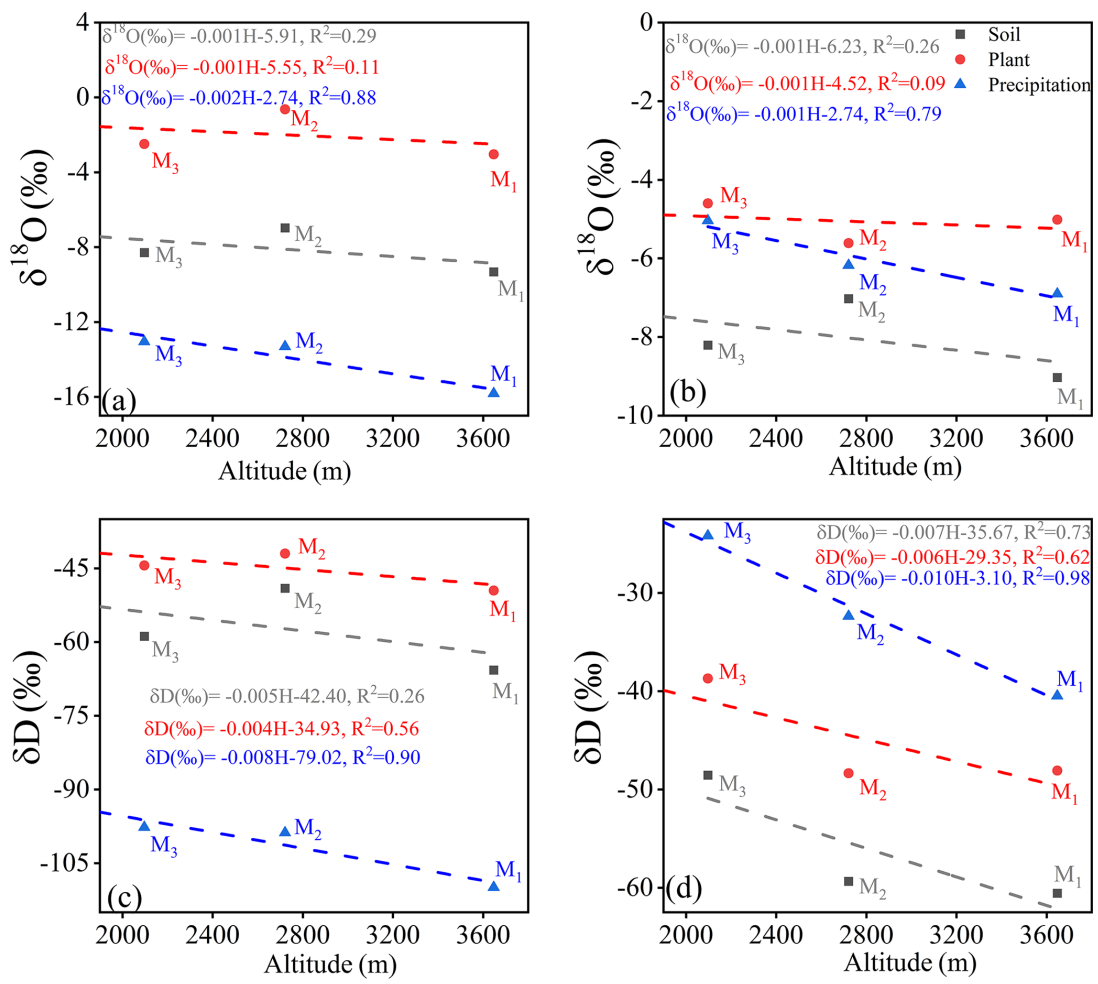

Figure 7. Relationship between different isotopes and altitudes in the dry season (a,c) and in the rainy season (b, d); $M_{1}$ stands for alpine meadows; $M_{2}$ stands for forests; and $M_{3}$ stands for arid foothills.

the rainy season, the squares of the correlation coefficients between precipitation $\delta^{18} \mathrm{O}$ and altitude and between precipitation $\delta \mathrm{D}$ and altitude are 0.79 and 0.98 , and the change rates of $\delta^{18} \mathrm{O}$ and $\delta \mathrm{D}$ are -0.12 and $-1.05 \%(100 \mathrm{~m})^{-1}$, respectively. In the dry season, the correlation coefficient squares between precipitation $\delta^{18} \mathrm{O}$ and altitude and between precipitation $\delta \mathrm{D}$ and altitude are 0.88 and 0.90 , respectively, and the rate of $\delta^{18} \mathrm{O}$ and $\delta \mathrm{D}$ change is -0.18 and $-0.79 \% \circ(100 \mathrm{~m})^{-1}$, respectively. We can see that the altitude effect of precipitation $\delta^{18} \mathrm{O}$ is stronger in the dry season $\left(R^{2}=0.88\right)$ than in the rainy season $\left(R^{2}=0.79\right)$. The results show that as the temperature increases, the temperature effect of precipitation $\delta^{18} \mathrm{O}$ masks the altitude effect, which leads to the weakening of the altitude effect of precipitation $\delta^{18} \mathrm{O}$. The relationship between soil water $\delta^{18} \mathrm{O}$ and altitude is stronger in the dry season $\left(R^{2}=0.26\right)$ than in the rainy season $\left(R^{2}=0.28\right)$. The relationship between plant water $\delta^{18} \mathrm{O}$ and altitude is stronger in the dry season $\left(R^{2}=0.11\right)$ than in the rainy season $\left(R^{2}=0.10\right)$; this is consistent with the changes in the altitude effect of precipitation isotopes.

\subsubsection{The influence of relative humidity and precipitation on the SPAC}

To find out the potential factors that control the isotope composition of the SPAC in different vegetation zones, we also analyzed the influence of relative humidity and precipitation on the $\delta^{18} \mathrm{O}$ of the SPAC. It can be seen from Fig. 8 and Table 4 that the greatest impact of relative humidity on the isotope composition of the SPAC appears in the arid foothills in the dry season, with a correlation coefficient of 0.38 . Although in the dry season, the square of the correlation coefficient between forest precipitation isotope and relative humidity is 0.78 , there is an inverse humidity relationship between the two, which may be related to the lack of precipitation samples in the dry season. The largest impact of precipitation on the isotopic composition of the SPAC occurs in the arid foothills in the rainy season, and the square of the correlation coefficient is 0.14 . It can also be seen from Fig. 8 that the influence of relative humidity and precipitation on precipitation isotopes is greater than that on plant water isotopes and soil water isotopes. The influence of relative humidity and precipitation on the isotopic composition of the SPAC in alpine meadows is greater than that in arid foothills and greater than that in forests. In general, the SPAC isotopic composition of alpine meadows, forests, and arid foothills has a weak precipitation effect, and the correlation with relative humidity is also weak.

By comparing the correlation of temperature, altitude, relative humidity, and precipitation with SPAC isotope composition in different vegetation zones, we can see that the correlation between temperature and altitude and SPAC isotope composition is stronger than that of relative humidity and precipitation. Temperature and altitude are potential factors 

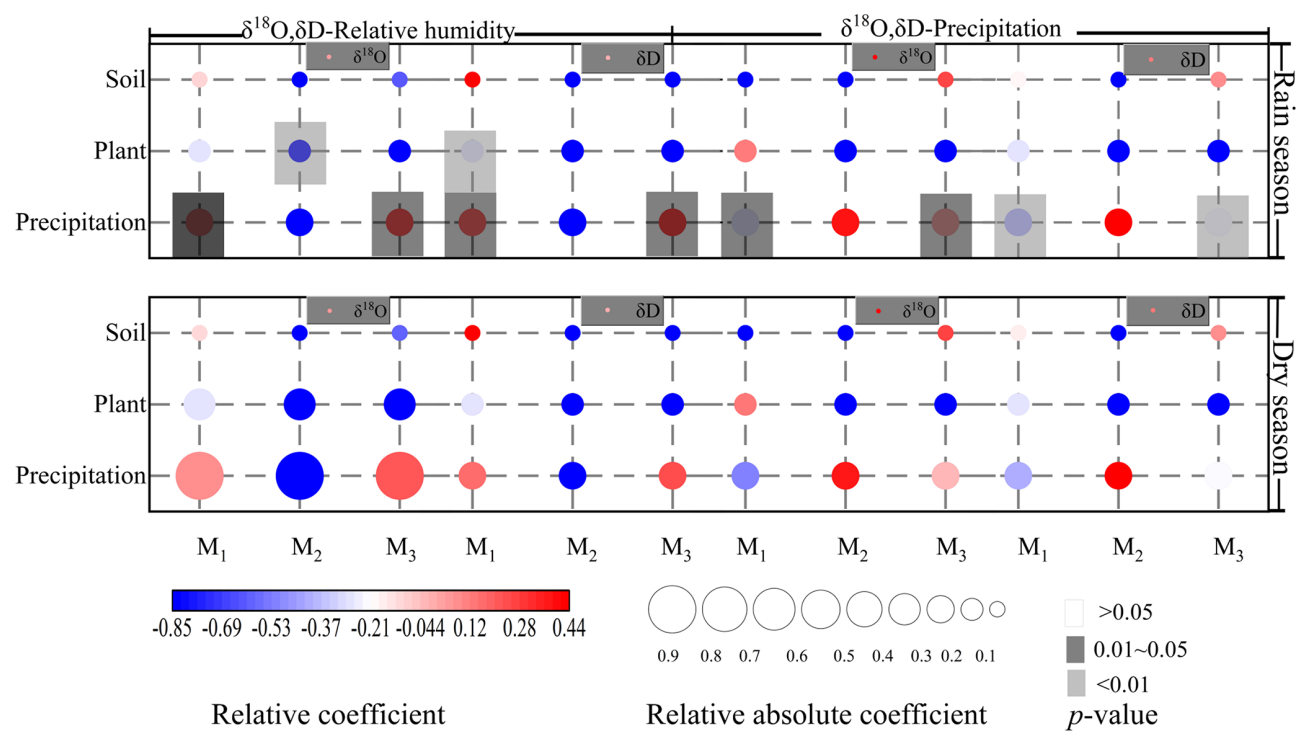

Figure 8. Relationship between different isotopes and relative humidity and precipitation; $M_{1}$ stands for alpine meadows; $M_{2}$ stands for forests; and $M_{3}$ stands for arid foothills.

Table 4. Correlation between different isotopes' $\delta^{18} \mathrm{O}$ and relative humidity and precipitation in different vegetation zones.

\begin{tabular}{|c|c|c|c|c|c|c|c|}
\hline \multirow{2}{*}{$\begin{array}{l}\text { Meteorological } \\
\text { parameters }\end{array}$} & \multirow[t]{2}{*}{ Isotope types } & \multicolumn{3}{|c|}{ Rainy season } & \multicolumn{3}{|c|}{ Dry season } \\
\hline & & Alpine meadow & Forest & Arid foothills & Alpine meadow & Forest & Arid foothills \\
\hline $\begin{array}{l}\text { Relative } \\
\text { humidity }\end{array}$ & Precipitation & $\begin{array}{l}y=-0.001 x-8.89 \\
R^{2}=0.001 \\
y=-0.11 x+6.11 \\
R^{2}=0.11 \\
y=-0.22 x+9.45 \\
R^{2}=0.28\end{array}$ & $\begin{array}{l}y=-0.03 x-5.21 \\
R^{2}=0.13 \\
y=0.08 x-10.53 \\
R^{2}=0.13 \\
y=0.02 x-9.50 \\
R^{2}=0.002\end{array}$ & $\begin{array}{l}y=-0.002 x-8.01 \\
R^{2}=0.002 \\
y=0.05 x-7.68 \\
R^{2}=0.04 \\
y=0.13 x+3.57 \\
R^{2}=0.29\end{array}$ & $\begin{array}{l}y=-0.01 x-8.39 \\
R^{2}=0.03 \\
y=-0.09 x+3.78 \\
R^{2}=0.10 \\
y=0.02 x-16.47 \\
R^{2}=0.002\end{array}$ & $\begin{array}{l}y=0.01 x-7.21 \\
R^{2}=0.07 \\
y=-0.02 x-0.28 \\
R^{2}=0.004 \\
y=0.16 x+4.33 \\
R^{2}=0.72\end{array}$ & $\begin{array}{l}y=-0.04 x-6.38 \\
R^{2}=0.38 \\
-\end{array}$ \\
\hline Precipitation & Precipitation & $\begin{array}{l}y=0.04 x-9.55 \\
R^{2}=0.15 \\
y=-0.07 x-1.09 \\
R^{2}=0.002 \\
y=-0.30 x-5.21 \\
R^{2}=0.09\end{array}$ & $\begin{array}{l}y=0.02 x-7.36 \\
R^{2}=0.01 \\
y=-0.06 x-5.01 \\
R^{2}=0.01 \\
y=-0.17 x-6.17 \\
R^{2}=0.05\end{array}$ & $\begin{array}{l}- \\
y=0.18 x-6.00 \\
R^{2}=0.05 \\
y=-0.28 x-2.84 \\
R^{2}=0.14\end{array}$ & $\begin{array}{l}y=-0.13 x-8.94 \\
R^{2}=0.18 \\
y=0.07 x-2.75 \\
R^{2}=0.03 \\
y=-0.14 x-14.24 \\
R^{2}=0.002\end{array}$ & $\begin{array}{l}y=-0.41 x-0.32 \\
R^{2}=0.06 \\
y=0.17 x-9.41 \\
R^{2}=0.11\end{array}$ & $\begin{array}{l}y=0.06 x-8.73 \\
R^{2}=0.06\end{array}$ \\
\hline
\end{tabular}

that control the isotope composition of the SPAC. However, in the dry season, there is a phenomenon that the temperature effect conceals the altitude effect.

\section{Conclusions}

This paper uses the hydrogen and oxygen isotope method to study the differences in and control factors of the SPAC in different vegetation zones. Temperature and altitude are the main control factors for the isotopic composition of the SPAC. From alpine meadows to forests to arid foothills, as the altitude decreases, the temperature effect of precipitation isotopes increases and the influence of temperature also in- creases. When the temperature is lower than $0^{\circ} \mathrm{C}$, the temperature effect of the vegetation zone is the strongest. In the dry season, there is a phenomenon that the temperature effect masks the altitude effect. With the increase in the soil depth, the soil water isotopes are gradually depleted. The soil water content of alpine meadows is the largest and increases with the soil depth, while the soil water content in forest decreases with the soil depth, and the soil water content of the arid foothills is the lowest in August. In the rainy season, plants mainly use precipitation, while forest plants mainly use soil water in the dry season. Alpine meadow plants do not directly use soil water because of the abundant precipitation and meltwater in the growing season. The groundwa- 
ter table exposed in the arid foothills can provide water for plants in the dry season. Forests and grasslands affect intercepting rainfall: they delay or hinder the formation of surface runoff and convert part of the surface runoff into soil flow and groundwater, which can provide part of the water resources for plants. To better understand the water cycle of the SPAC at different temperatures and altitudes in high mountain areas, long-term observations of different plants are needed to provide a theoretical basis for the rational and practical use of water resources in arid mountainous areas.

Data availability. The data that support the findings of this study are openly available at https://data.mendeley.com/datasets/ d5kzm92nn3/1 (Zhu et al., 2021b).

Author contributions. GZ and YL conceived the idea of the study; $\mathrm{ZZ}$ analyzed the data; ZS and LY were responsible for field sampling; LS participated in the experiment; KZ participated in the drawing; YL wrote the paper; LS and LW checked and edited the language. All authors discussed the results and revised the manuscript.

Competing interests. The contact author has declared that neither they nor their co-authors have any competing interests.

Disclaimer. Publisher's note: Copernicus Publications remains neutral with regard to jurisdictional claims in published maps and institutional affiliations.

Acknowledgements. This research was financially supported by the National Natural Science Foundation of China (41661005, 41867030, 41971036). The authors sincerely thank their colleagues at Northwest Normal University for their help in fieldwork, laboratory analysis, and data processing.

Financial support. This research has been supported by the National Natural Science Foundation of China (grant nos. 41661005, 41867030, 41971036).

Review statement. This paper was edited by Aninda Mazumdar and reviewed by two anonymous referees.

\section{References}

Araguás-Araguás, L., Froehlich, K., and Rozanski, K.: Stable isotope composition of precipitation over southeast Asia, J. Geophys. Res.-Atmos., 103, 28721-28742, https://doi.org/10.1029/98JD02582, 1998.
Bam, E. and Ireson, A. M.: Quantifying the wetland water balance: a new isotope-based approach that includes precipitation and infiltration, J. Hydrol., 570, 185-200, https://doi.org/10.1016/j.jhydrol.2018.12.032, 2018.

Chen, X. L., Chen, Y. N., and Chen, Y. N P.: Water use relationship of desert riparian forest in lower reaches of Heihe River, Chinese Journal of Eco-Agriculture, 22, 972-979, https://doi.org/10.1007/s11430-013-4680-8, 2014.

Christopher, T., Solomon, J, J., Cole, R. R., and Doucett, M.: The influence of environmental water on the hydrogen stable isotope ratio in aquatic consumers, Oecologia, 161, 313-324, https://doi.org/10.1007/s00442-009-1370-5, 2009.

Coenders-Gerrits, A. M, J., van der Ent, R. J., Bogaard, T. A., WangErlandsson, L., Hrachowitz, M., Savenije, and Savenije, H. H. G.: Uncertainties in transpiration estimates, Nature, 506, 74-87, https://doi.org/10.1038/nature12925, 2014.

Coplen, T.: Stable isotope hydrology: Stable isotope hydrology: deuterium and oxygen 18 in the water cycle, EOS T. Am. Geophys. Un., 63, 861-862, https://doi.org/10.1029/EO063i045p00861, 2013.

Cortes, A. and Farvolden, R. N.: Isotope studied of precipitation and groundwater in the Sierra de las Cruces, Mexico, J. Hydrol., 107, 147-153, https://doi.org/10.1016/0022-1694(89)90055-3, 1989.

Craig, H.: Isotopic variations in meteoric water, Science, 133, 1702-1703, https://doi.org/10.1126/science133.3465.1702, 1961.

Csilla, F., Györgyi, G., Zsófia, B., and Eszter, T.: Impact of expected climate change on soil water regime under different vegetation conditions, Biologia, 69, 1510-1519, https://doi.org/10.2478/s11756-014-0463-8, 2014.

Dai, J. J., Zhang, X. P., Luo, Z. D., Wang, R., Liu, Z. L., He, X. G., and Guan, H. D.: Variation of the stable isotopes of water in the soil-plant-atmosphere continuum of a Cinnamomum camphora woodland in the East Asian monsoon region, J. Hydrol., 589, 125199, https://doi.org/10.1016/j.jhydrol.2020.125199, 2020.

Darling, W. G., Bath, A. H., and Talbot, J. C.: The O and H stable isotope composition of freshwaters in the British Isles. 2. Surface waters and groundwater, Hydrol. Earth Syst. Sci., 7, 183-195, https://doi.org/10.5194/hess-7-183-2003, 2003.

Dawson, T. E.: Water sources of plants as determined from xylemwater isotopic composition: perspectives on plant competition, distribution, and water relations stable isotopes and plant carbon water relations, stable isotopes and plant carbon-water relations, Stable Isotopes and Plant carbon-water relations. Academic Press, 465-496, 1993.

Dawson, T. E. and Ehleringer, J. R.: Streamside trees that do not use stream water, Nature, 350, 335-337, https://doi.org/10.1038/350335a0, 1991.

Detjen, M., Sterling, E., and Gómez, A.: Stable isotopes in barnacles as a tool to understand green sea turtle (Chelonia mydas) regional movement patterns, Biogeosciences, 12, 7081-7086, https://doi.org/10.5194/bg-12-7081-2015, 2015.

Durand, J.-L., Bariac, T., Ghesquière, M., Biron, P., Richard, P., Humphreys, M., and Zwierzykovski, Z.: Ranking of the depth of water extraction by individual grass plants, using natural ${ }^{18} \mathrm{O}$ isotope abundance, Environ. Exp. Bot., 60, 137-144, https://doi.org/10.1016/j.envexpbot.2006.09.004, 2007. 
Ehleringer, L.: Stable isotope composition of stem and leaf water: applications to the study of plant water use, Funct. Ecol., 5, 270277, https://doi.org/10.2307/2389264, 1991.

Gao, J., Tian, L, D., Liu, Y, Q., and Gong, T. L.: Oxygen isotope variation in the water cycle of the Yamzho lake Basin in southern Tibetan Plateau, Chinese Sci. Bull., 2758-2765, https://doi.org/10.1007/s11434-009-0487-6, 2009.

Gao, J., Yao, T., Tian, L. D., Risi, C., and Hoffmann, G.: Precipitation water stable isotopes in the south Tibetan Plateau: observations and modeling, J. Climate, 24, 3161-3178, https://doi.org/10.1175/2010JCLI3736.1, 2011.

Hou, S. B., Song, X. F., Jie, Y. J., Liu, X., and Zhang, G. Y.: Stable isotopes characters in the process of precipitation and infiltration in taihang mountainous region, Resources Science, 23, 86-92, http://hdl.handle.net/2268/90707, 2008.

Hua, M. Q., Zhang, X. P., Yao, T. C., Luo, Z. D., Zhou, H., Rao, Z. G., and He, X. G.: Dual effects of precipitation and evaporation on lake water stable isotope composition in the monsoon region, Hydrol. Process., 33, 2192-2205, https://doi.org/10.1002/hyp.13462, 2019.

Jasechko, S., Sharp, Z. D., Gibson, J. J., Birkes, S. J., Yi, Y., and Fawcett, P. J.: Terrestrial water fluxes dominated by transpiration, Nature, 496, 347-351, https://doi.org/10.1038/nature11983, 2013.

Javaux, M., Rothfuss, Y., Vanderborght, J., Vereecken, H., and Brüggemann, N.: Isotopic composition of plant water sources, Nature, 536, E1-E3, https://doi.org/10.1038/nature18946, 2016.

Li, C. C., Huang, M. S., Liu, J., Ji, S. P., and Zhao, R. Q.: Isotope-based water-use efficiency of major greening plants in a sponge city in northern China, PloS one, 14, https://doi.org/10.1371/journal.pone.0220083, 2019.

Li, L. F., Yan, J. P., Liu, D. M., Chen, F., and Ding, J. M.: Changes in soil water content under different vegetation conditions in aridsemi-arid areas and analysis of vegetation construction methods, Bulletin of Soil and Water Conservation, 29, 18-22, 2009.

Li, S. G., Maki, T., Atsuko, S., and Michiaki, S.: Seasonal variation in oxygen isotope composition of waters for a montane larch forest in Mongolia, Trees, 20, 122-130, https://doi.org/10.1007/s00468-005-0019-1, 2006.

Liu, W., Wang, P., Li, J., Liu, W., and Li, H.: Plasticity of source-water acquisition in epiphytic, transitional and terrestrial growth phases of Ficus tinctoria, Ecohydrology, 7, 1524-1533, https://doi.org/10.1002/eco.1475, 2015.

McCole, A. A. and Stern, L. A.: Seasonal water use patterns of Juniperus ashei on the Edwards Plateau, Texas, based on stable isotopes in water, J. Hydrol., 342, 238-248, https://doi.org/10.1016/j.jhydrol.2007.05.024, 2007.

Meissner, K., Schwendenmann, H., and Dyckmans.: Soil water uptake by trees using water stable isotopes $\left(\delta \mathrm{D}\right.$ and $\left.\delta^{18} \mathrm{O}\right)-\mathrm{a}$ method test regarding soil moisture, texture and carbonate, Plant Soil., 376, 327-335, https://doi.org/10.1007/s11104-013-1970-z, 2014.

Meng, X. Q., Wen, X. F., Zhang, X. Y., Han, J. Y., Sun, X. M., and $\mathrm{Li}, \mathrm{X}$. B.: Influence of organics on the determination of $\delta^{18} \mathrm{O}$ and $\delta \mathrm{D}$ of plant leaves and stalk water by infrared spectroscopy, Chinese Journal of Eco-Agriculture, 20, 1359-1365, 2012.

Nie, Y. P., Chen, H. S., Wang, K, L., and Ding, Y. L.: Rooting characteristics of two widely distributed woody plant species growing in different karst habitats of southwest China, Plant. Ecol., 215, 1099-1109, https://doi.org/10.1007/s11258-014-0369-0, 2014.

Nlend, B., Celle-Jeanton, H., Risi, C., Pohl, B., Huneau, F., Ngo Boum-Nkot, S., Seze, G., Roucou, P., Camberlin, P., Etame, J., and Ketchemen-Tandia, B.: Identification of processes that control the stable isotope composition of rainwater in the humid tropical west-central Africa, J. Hydrol., 584, 124650, https://doi.org/10.1016/j.jhydrol.2020.124650, 2020.

Price, R. M., Skrzypek, G., Grierson, P. F., Swart, P. K , and Fourqurean, J. W.: The use of stable isotopes of oxygen and hydrogen to identify water sources in two hypersaline estuaries with different hydrologic regimes, Mar. Freshwater Res., 63, 952-966, https://doi.org/10.1071/MF12042, 2012.

Raco, B., Dotsika, E., Feroni, A. C., Battaglini, R., and Poutoukis, D.: Stable isotope composition of italian bottled waters, J. Geochem. Explor., 124, 203-211, https://doi.org/10.1016/j.gexplo.2012.10.003, 2013.

Rodriguez-Iturbe, I., Porporato, A., Laio, F., and Ridolfi, L.: Plants in water-controlled ecosystems: active role in hydrologic processes and response to water stress, Adv. Water. Resour., 24, 707-723, https://doi.org/10.1016/S0309-1708(01)00005-7, 2001.

Rothfuss, Y. and Javaux, M.: Reviews and syntheses: Isotopic approaches to quantify root water uptake: a review and comparison of methods, Biogeosciences, 14, 2199-2224, https://doi.org/10.5194/bg-14-2199-2017, 2017.

Rozanski, K., Araguas-Araguas, L., and Gonfifiantini, R.: Relation between long-term trends of oxygen-18 isotope composition of precipitation and climate, Science, 258, 981-985, https://doi.org/10.1126/science.258.5084.981, 1992.

Schlesinger, W. H. and Jasechko, S.: Transpiration in the global water cycle, Agr. Forest Meteorol., 189, 115-117, https://doi.org/10.1016/j.agrformet.2014.01.011, 2014.

Schwendenmann, L., Pendall, E., Sanchez-Bragado, R., Kunert, N., Hölscher, D.: Tree water uptake in a tropical plantation varying in tree diversity: Interspecific differences, seasonal shifts and complementarity, Ecohydrology, 8, 1-12, https://doi.org/10.1002/eco.1479, 2015.

Shou, W. K., Hu, F. L., Alamusa., and Liu, Z. M.: Methods for studying water cycle and water sources in arid regions based on spac system, Chinese Journal of Ecology, 32, 2194-2202, 2013.

Smith, G. I., Friedman, I., Gleason, J. D., and Warden, A.: Stable isotope composition of waters in southeastern California: 2. groundwaters and their relation to modern precipitation, J. Geophys. Res-Atmos., 97, 5813-5823, https://doi.org/10.1029/92JD00183, 1992.

Song, X., Barbour, M. M., Farquhar, G. D., Vann, D. R., and Helliker, B. R.: Transpiration rate relates to within and across species variations in effective path length in a leaf water model of oxygen isotope enrichment, Plant Cell Environ., 36, 1338-1351, https://doi.org/10.1111/pce.12063, 2013.

Song, X. F., Xia, J., Yu, J. J., and Liu, C. M.: Application of environmental isotope techniques to study the hydrological cycle mechanism of typical watersheds in North China, Advances in Geographical Sciences, 21, 527-537, 2002.

Sprenger, M., Tetzlaff, D., and Soulsby, C.: Soil water stable isotopes reveal evaporation dynamics at the soil-plant-atmosphere interface of the critical zone, Hydrol. Earth Syst. Sci., 21, 38393858, https://doi.org/10.5194/hess-21-3839-2017, 2017. 
Sun, S. F., Huang, J. H., Lin, G. H. , Zhao, W., and Han, X. G.: Application of stable isotope technique in the study of plant water use, Acta Ecologica Sinica, 25, 2362-2371, https://doi.org/10.1360/982004-755, 2005 (in Chinese).

Wan, Q. Z., Zhu, G. F., Guo, H. W., Zhang, Y., Pan, H. X., and Yong, L. L.: Influence of vegetation coverage and climate environment on soil organic carbon in the Qilian mountains, Sci. Rep.-UK, 9, 17623. https://doi.org/10.1038/s41598-019-53837-4, 2019.

Wang, S. Y., Wang, Q. L., Wu, J, K., He, X. B., and Wang, L. H.: Characteristics of stable isotopes in precipitation and moisture sources in the headwaters of the Yangtze River, Environm. Sci., 40, 2615-2623, https://doi.org/10.13227/j.hjkx.201811140, 2019.

Wei, W., Xie, B., Zhang, X., and Zhang, J.: Spatial heterogeneity of soil moisture and vegetation cover in Shiyang river basin, northwest China, IOP Conference Series: Earth and Environmental Science., 237, 052003, https://doi.org/10.1088/17551315/237/5/052003, 2019.

West, A. G., Patrickson, S. J., and Ehleringer, J. R.: Water extraction times for plant and soil materials used in stable isotope analysis, Rapid Commun. Mass Sp., 20, 1317-1321. https://doi.org/10.1002/rcm.2456, 2010.

Western, A. W. and Grayson, R. B.: The tarrawarra data set: soil moisture patterns, soil characteristics, and hydrological flux measurements, Water. Resour. Res., 34, 2765-2768. https://doi.org/10.1029/98WR01833, 1998.

White, J., Cook, E., Lawrence, J. R., and Broecker, W. S.: The $\mathrm{D} / \mathrm{H}$ ratios of sap in trees: implications for water sources and tree ring D/H ratios, Geochim. Cosmochim. Acta, 49, 237-246, https://doi.org/10.1016/0016-7037(85)90207-8, 1985.
Yang, B., Wen, X., and Sun, X.: Seasonal variations in depth of water uptake for a subtropical coniferous plantation subjected to drought in an east Asian monsoon region, Agr. Forest Meteorol., 201, 218-228, https://doi.org/10.1016/j.agrformet.2014.11.020, 2015.

Yu, J. J., Song, X. F., Liu, X. C., Yang, C., Tang, C. Y., and Li, F. D.: A study of groundwater cycle in yongding river basin by using $\delta \mathrm{D}, \delta^{18} \mathrm{O}$ and hydrochemical data, Journal of Natural Resources, 22, 415-423, 2007.

Zhou, H., Zhao, W. Z., Zheng, X. J., and Li, S. J.: Root distribution of Nitraria sibirica with seasonally varying water sources in a desert habitat, J. Plant Res., 128, 613-622, 2015.

Zhou, J. J., Zhao, Y. R., Huang, P., and Liu. C. F.: Impacts of ecological restoration projects on the ecosystem carbon storage of inland river basin in arid area, China, Ecol. Indic., 118, 106803, https://doi.org/10.1016/j.ecolind.2020.106803, 2020.

Zhu, G. F., Guo, H. W., Qin, D. H., Pan, H. X., and Ma, X. G.: Contribution of recycled moisture to precipitation in the monsoon marginal zone: estimate based on stable isotope data, J. Hydrol., 569, 423-435, https://doi.org/10.1016/j.jhydrol.2018.12.014, 2018.

Zhu, G. F., Zhang, Z. X., Guo H. W., Zhang, Y., Yong, L. L., Wan, Q. Z., Sun, Z. G., and Ma, H. Y.: Below-Cloud Evaporation of Precipitation Isotope over Mountain-oasis-desert in Arid Area, J. Hydrometeorol., 22, 2533-2545, https://doi.org/10.1175/JHMD-20-0170.1, 2021a.

Zhu, G. F.: Stable water isotope monitoring network of different water bodies in Shiyang River Basin, a typical arid river in China (Supplemental Edition 20210808) [data set], https://doi.org/10.17632/d5kzm92nn3.1, 2021b. 